\title{
Population dynamics of soil bacteria in some areas of Midnapore coastal belt, West Bengal, India
}

\author{
Syed Afrin Azmi ${ }^{1} \cdot$ Soumendranath Chatterjee $^{1}$
}

Received: 5 June 2015/ Accepted: 2 September 2015/Published online: 23 January 2016

(c) The Author(s) 2016. This article is published with open access at Springerlink.com

\begin{abstract}
In this present study the population dynamics of the soil bacteria of some coastal villages, namely Padima, Jatimati, Chanpabani, Palsandapur, Bhagibaharampur, Duttapur, Gangadharpur, Gobindabasan, Somaibasan of Digha, West Bengal, India, was determined. In these villages the aerobic heterotrophic, Gram-negative, spore-forming, starch-hydrolyzing, Pseudomonas, nitratereducing, denitrifying, asymbiotic $\mathrm{N}_{2}$ fixing, nitrifying, phosphate-solubilizing bacterial populations ranged from 1.22 to $2.67 \times 10^{6}, 0.09-1.63 \times 10^{5}, 1.53-3.68 \times 10^{5}$, $2.22-4.06 \times 10^{5}, \quad 0.02-0.04 \times 10^{5}, \quad 0.35-1.33 \times 10^{5}$, $0.07-0.82 \times 10^{5}, \quad 0.58-2.50 \times 10^{5}, \quad 0.13-2.35 \times 10^{5}$, $0.05-1.9 \times 10^{5} \mathrm{cfu} / \mathrm{g}$ dry soil, respectively. The organic carbon content of the soil samples ranged from 0.61 to $0.93 \%$. The available nitrogen and phosphate in the soils of the study area varied from 11.2 to 29.5 and $230.8-503.09 \mathrm{mg} / \mathrm{kg}$, respectively. The one-way ANOVA revealed significant variations $(p<0.05)$ in the microbial diversity with respect to different locations of the study site. Shannon-Wiener and Simpson Index of the study areas ranged from 1.56 to 1.88 and $3.85-5.73$, respectively. Jatimati showed comparatively higher diversity index among the villages of the study area. From principal component analysis, three components were extracted having the Eigen values of 3.541, 1.603 and 1.391, respectively. Agglometric hierarchial cluster analysis in respect of the number of different bacterial groups in different places of the study area showed that the denitrifying,
\end{abstract}

Soumendranath Chatterjee

soumen.microbiology@gmail.com

1 Parasitology and Microbiology Research Laboratory, Department of Zoology, The University of Burdwan, Burdwan, West Bengal 713104, India nitrate reducing, asymbiotic nitrogen-fixing and sporeforming bacteria formed a cluster while Pseudomonas differed from them forming another cluster and nitrifying, Gram negative, phosphate-solubilising and starch-hydrolyzing bacteria formed another different cluster. This variation of the soil bacteria might be dependent on the microhabitat present in different locations of the study area.

Keywords Population dynamics - ANOVA . Shannon-Wiener Index $\cdot$ Simpson Index $\cdot$ PCA $\cdot$ AHC

\section{Introduction}

In terrestrial and aquatic ecosystems, soil is an important abiotic component that regulates the formation of assemblage of several interacting organisms, including microbes. Microorganisms are ubiquitous in nature and influence all known ecosystems on earth (Atlas and Bertha 1998). The ubiquity of microorganisms is attributed mainly to their small size, easy dispersal, adaptation to diverse habitats and ability to utilize wide variety of substrates as nutrient source (Pandey et al. 2007). The soil-dwelling microbes can be referred as the "Biological engine" of the earth as they play a pivotal role in many fundamental nutrient cycling processes, soil structure dynamics, pollution degradation and regulation of different plant communities (Breure 2004). Microbes are also responsible for soil aeration and soil fertility which are among the crucial aspects of soil function. Production of soil organic matter increases the capacity of the soil to maintain its functional structure once it is formed. The soil organic matter is directly derived from the combined biological activity of plants, microbes, animals and abiotic factors. Soil microbial 
community mainly consists of five major groups, i.e. bacteria, actinomycetes, fungi, algae and protozoa (Holt 1986). Among them bacterial population is generally much higher than other groups (Alexander 1978). To understand the complexity of the interaction mediated by soil microbes, the evaluation of soil microbial diversity is essential. The determination of soil microbes is based on enumeration of laboratory culture of the isolates and also on 16S rDNA sequence analysis of the microbes (Seckbach 2000; Satyanarayana et al. 2005). Various works have been done on soil microbial diversity in different regions of India (Das and Dangar 2007, 2008; Chatterjee et al. 2007) but no such work on bacterial diversity has yet been done in the coastal areas of Digha, West Bengal, India. Coastal zone is the transitional zone between the terrestrial land and sea which are indeed unique places in our global geography, so various physical and topological parameters of the coastal areas should be maintainedd and observe periodically (Visalatchi and Raj Chandar 2012). Though the coastal areas of Digha is an important sea-shore region of India, it is neglected in terms of basic soil research. Previously no work was reported either on the population dynamics of the soil bacteria or on the relationship between soil microflora and soil physicochemical properties of coastal areas of Digha. In this context, the present study has been carried out to determine the diversity of soil bacteria and the physicochemical properties of the soil of different villages of the coastal areas of Digha, West Bengal, India.

\section{Materials and methods}

\section{Soil collection}

The soil samples were collected from nine village areas of Midnapore coastal belt, West Bengal, India: [Padima $\left(21^{\circ} 37^{\prime} 39.99^{\prime \prime} \mathrm{N}, 87^{\circ} 29^{\prime} 28.81^{\prime \prime} \mathrm{E}\right)$, Jatimati $\left(21^{\circ} 37^{\prime} 40.90^{\prime \prime} \mathrm{N}\right.$, $\left.87^{\circ} 29^{\prime} 46.66^{\prime \prime} \mathrm{E}\right), \quad$ Chanpabani $\quad\left(21^{\circ} 37^{\prime} 39.89^{\prime \prime} \mathrm{N}, \quad 87^{\circ} 30^{\prime}\right.$ $\left.22.64^{\prime \prime} \mathrm{E}\right)$, Palsandapur $\left(21^{\circ} 37^{\prime} 30.36^{\prime \prime} \mathrm{N}, 87^{\circ} 30^{\prime} 04.46^{\prime \prime} \mathrm{E}\right)$, Bhagibaharampur $\left(21^{\circ} 37^{\prime} 36.48^{\prime \prime} \mathrm{N}, 87^{\circ} 30^{\prime} 44.42^{\prime \prime} \mathrm{E}\right)$, Duttapur $\left(21^{\circ} 36^{\prime} 57.78^{\prime \prime} \mathrm{N}, \quad 87^{\circ} 29^{\prime} 29.71^{\prime \prime} \mathrm{E}\right)$, Gadadharpur $\left(21^{\circ} 37^{\prime} 05.81^{\prime \prime} \mathrm{N}, 87^{\circ} 30^{\prime} 04.41^{\prime \prime} \mathrm{E}\right)$, Gobindabasan $\left(21^{\circ} 37^{\prime}\right.$ $\left.36.23^{\prime \prime} \mathrm{N}, 87^{\circ} 31^{\prime} 18.36^{\prime \prime} \mathrm{E}\right)$ and Somaibasan $\left(21^{\circ} 37^{\prime} 50.71^{\prime \prime} \mathrm{N}\right.$, $\left.87^{\circ} 32^{\prime} 11.37^{\prime \prime} \mathrm{E}\right)$ ] during November 2013-February 2014. The topmost soil $(1 \mathrm{~cm})$ was scrapped off and then about $100 \mathrm{~g}$ of soil from each area was collected in sterile polythene bags sealed with rubber bands.

\section{Soil analysis}

The soil samples were taken to the Microbiology and Parasitology Research Laboratory, The University of Burdwan, for both physico-chemical and microbial analysis.
To determine the heterotrophic viable aerobic bacterial population, soil samples were diluted up to $10^{-5}$ and a $10 \mu \mathrm{l}$ soil suspension $\left(10^{-5}\right)$ was mixed with $100 \mathrm{ml}$ nutrient agar (peptone $5 \mathrm{~g} / \mathrm{l}$, beef extract $3 \mathrm{~g} / \mathrm{l}$, agar $2 \mathrm{~g} / \mathrm{l}$, $\mathrm{pH}$ 7) and incubated at $30 \pm 1{ }^{\circ} \mathrm{C}$ in the BOD incubator. To determine different groups of bacteria separately, $10 \mu \mathrm{l}$ of soil suspension $\left(10^{-4}\right)$ was mixed with $100 \mathrm{ml}$ of different specific media distributed in five plates and incubated at $30 \pm 1{ }^{\circ} \mathrm{C}$ in the BOD incubator. Soil suspension was pasteurized at $60{ }^{\circ} \mathrm{C}$ for $30 \mathrm{~min}$ for enrichment culture of the spore formers. The starch-hydrolyzing bacteria were enumerated by incubating the soil on starch agar media for $24 \mathrm{~h}$ and counting the number of bacterial colony producing halo zone after flooding with Gram's iodine. The nitrifying bacteria were recorded after 5-30 days (5 day intervals) from the date of incubation. But all other groups of bacterial populations were counted after 3-day incubation. The aerobic heterotrophic and spore-forming bacteria were enumerated using nutrient agar media following the standard methods. To visualize Gram-negative bacteria, crystal violet (peptone $5 \mathrm{~g} / \mathrm{l}$, beef extract $3 \mathrm{~g} / \mathrm{l}$, lactose $10 \mathrm{~g} / \mathrm{l}$, crystal violet $0.0033 \mathrm{~g} / \mathrm{l}$, agar $15 \mathrm{~g} / \mathrm{l}, \mathrm{pH} 6.8 \pm 0.1$ ) was added to the medium before plating. Pseudomonas population were enumerated by incubating the soil suspension on Pseudomonas isolation agar [peptic digest of animal tissue $20 \mathrm{~g} / \mathrm{l}$, magnesium chloride $1.4 \mathrm{~g} / \mathrm{l}$, potassium sulfate $10 \mathrm{~g} / \mathrm{l}$, triclosan (Irgasan) $0.025 \mathrm{~g} / \mathrm{l}$, Agar $13.6 \mathrm{~g} / \mathrm{l}, \mathrm{pH} 7.0$ ] for $72 \mathrm{~h}$. Nitrifying bacteria was enumerated on Winogradsky's medium containing $\left(\mathrm{NH}_{4}\right)_{2} \mathrm{SO}_{4}(1.0 \mathrm{~g} / \mathrm{l})$ and the colonies were visualized (pink colour) by flooding the plates with sulphanilic acid reagent. The inorganic phosphate solubilizing bacteria were determined from the halo zone formation around the colonies on the insoluble phosphate $\left[\mathrm{Ca}_{3}\left(\mathrm{PO}_{4}\right)_{2}\right]$ containing medium. The asymbiotic nitrogenfixing bacteria were counted on nitrogen-free medium (Pelczar et al. 1957; Lacey 1997; Chatterjee et al. 2014). The physico-chemical parameters of the soil samples were measured following the standard methods (Issac and Johnson 1984; Sumner and Miller 1996; Evangelou 1998).

\section{Statistical analyses}

Shannon-Wiener Index and Simpson Index were calculated to determine the species diversity and richness of the bacterial population of the soil samples collected from coastal areas of Digha. The data obtained on the different groups of bacteria present in the soil samples of Digha were subjected to agglomerative hierarchial cluster analysis. Principal component analysis (PCA) was done to represent a relationship between the various groups of bacteria (Manly 1994; Zar 1999; Kinnear and Gray 2000). 


\section{Result}

In the village areas of the coastal areas of Digha, the aerobic heterotrophic, Gram negative, spore-forming, starch-hydrolyzing, Pseudomonas, nitrate-reducing, de nitrifying, asymbiotic $\mathrm{N}_{2}$ fixing, nitrifying, phosphatesolubilizing bacterial populations ranged from 1.22 to $2.67 \times 10^{6}, \quad 0.09-1.63 \times 10^{5}, \quad 1.53-3.68 \times 10^{5}$, $2.22-4.06 \times 10^{5}, \quad 0.02-0.04 \times 10^{5}, \quad 0.35-1.33 \times 10^{5}$, $0.07-0.82 \times 10^{5}, \quad 0.58-2.50 \times 10^{5}, \quad 0.13-2.35 \times 10^{5}$, $0.05-1.9 \times 10^{5} \mathrm{cfu} / \mathrm{g}$ dry soil, respectively (Table 1 ). In soil samples of Palsandapur, aerobic heterotrophic population, Gram-negative and phosphate-solubilising bacterial population were higher than in other regions of the study area. The spore-forming bacterial population was found to be higher in the soil samples of Chanpabani than that of Padima, Jatimati, Palsandapur, Bhagibaharampur, Duttapur, Gadadharpur, Gobindabasan and Somaibasan. The soil samples of Gadadharpur area contained higher number of starch-hydrolyzing, Pseudomonas and asymbiotic nitrogen-fixing bacteria than other villages of the present study area. Nitrate-reducing and de nitrifying bacterial population were comparatively higher in Jatimati village in respect of other villages of the study sites. In soil samples of Gobindabasan area, the nitrifying bacterial population was higher than that in Padima, Jatimati, Chanpabani, Palsandapur, Bhagibaharampur, Duttapur, Gadadharpur and Somaibasan area. The organic carbon content of the soil samples ranged from 0.61 to $0.93 \%$ and found to be higher in soil samples of Palsandapur $(0.93 \%)$ than other villages of the study area. The available nitrogen in the soils of the study area varied from 11.2 to $29.5 \mathrm{mg} / \mathrm{kg}$ and was highest in Gadadharpur area $(29.5 \mathrm{mg} / \mathrm{kg})$. The available phosphate content in the soil samples of the coastal areas of Digha ranged from 230.8 to $503.09 \mathrm{mg} / \mathrm{kg}$. In the Palsandapur area, the phosphate content was much higher $(503.09 \mathrm{mg} / \mathrm{kg})$ than other villages of our study area. The soil salinity ranged between 5.2 and $23.2 \mathrm{ds} / \mathrm{m}$ in the study area. The soil salinity was found to be lower in Palsandapur area and was comparatively higher in Gobindabasan area (Table 2). The results of the one-way ANOVA revealed significant variations $(p<0.05)$ in the microbial diversity with respect to different locations of the study site. Agglometric hierarchial cluster analysis (AHC) in respect of the number of different bacterial groups in different places of the study area showed that the denitrifying, nitrate-reducing, asymbiotic nitrogen-fixing and spore-forming bacteria formed a cluster in respect of their distribution pattern while Pseudomonas differed from them forming another cluster. Nitrifying, Gram-negative, phosphate-solubilising and starch-hydrolyzing bacteria formed a different cluster (Fig. 1). From principal

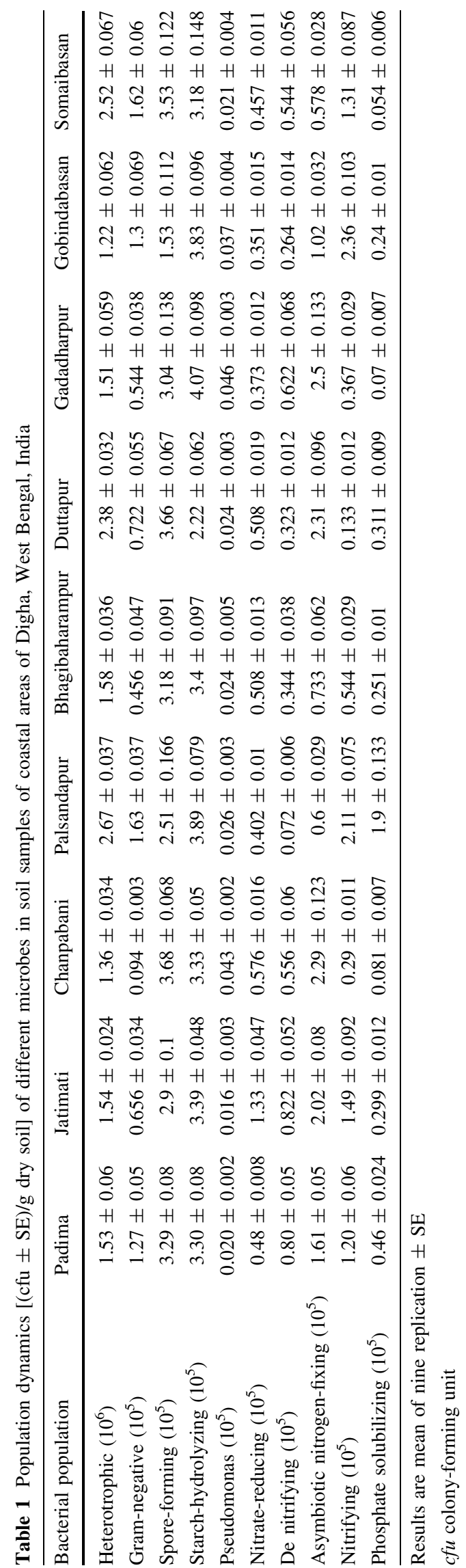

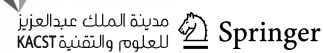


Table 2 Physico-chemical parameters of the soil samples collected from different areas of coastal areas of Digha, West Bengal

\begin{tabular}{|c|c|c|c|c|}
\hline Place & Organic carbon $(\%)$ & Nitrogen $(\mathrm{mg} / \mathrm{kg})$ & Phosphate $(\mathrm{mg} / \mathrm{kg})$ & Salinity (ds/m) \\
\hline Padima & 0.71 & 21.32 & 245.26 & 9.7 \\
\hline Jatimati & 0.85 & 29.4 & 244.78 & 10.3 \\
\hline Chanpabani & 0.68 & 20.12 & 230.91 & 11.2 \\
\hline Palsandapur & 0.93 & 18.75 & 503.09 & 5.2 \\
\hline Bhagibaharampur & 0.83 & 12.6 & 243.81 & 10.6 \\
\hline Duttapur & 0.90 & 16.5 & 244.92 & 20.8 \\
\hline Gadadharpur & 0.85 & 29.5 & 230.75 & 15.2 \\
\hline Gobindabasan & 0.61 & 11.2 & 243.8 & 23.2 \\
\hline Somaibasan & 0.89 & 23.2 & 230.8 & 18.7 \\
\hline
\end{tabular}

Fig. 1 Agglometric hierarchical cluster analysis of the soil bacterial isolates of different villages of Digha, West Bengal

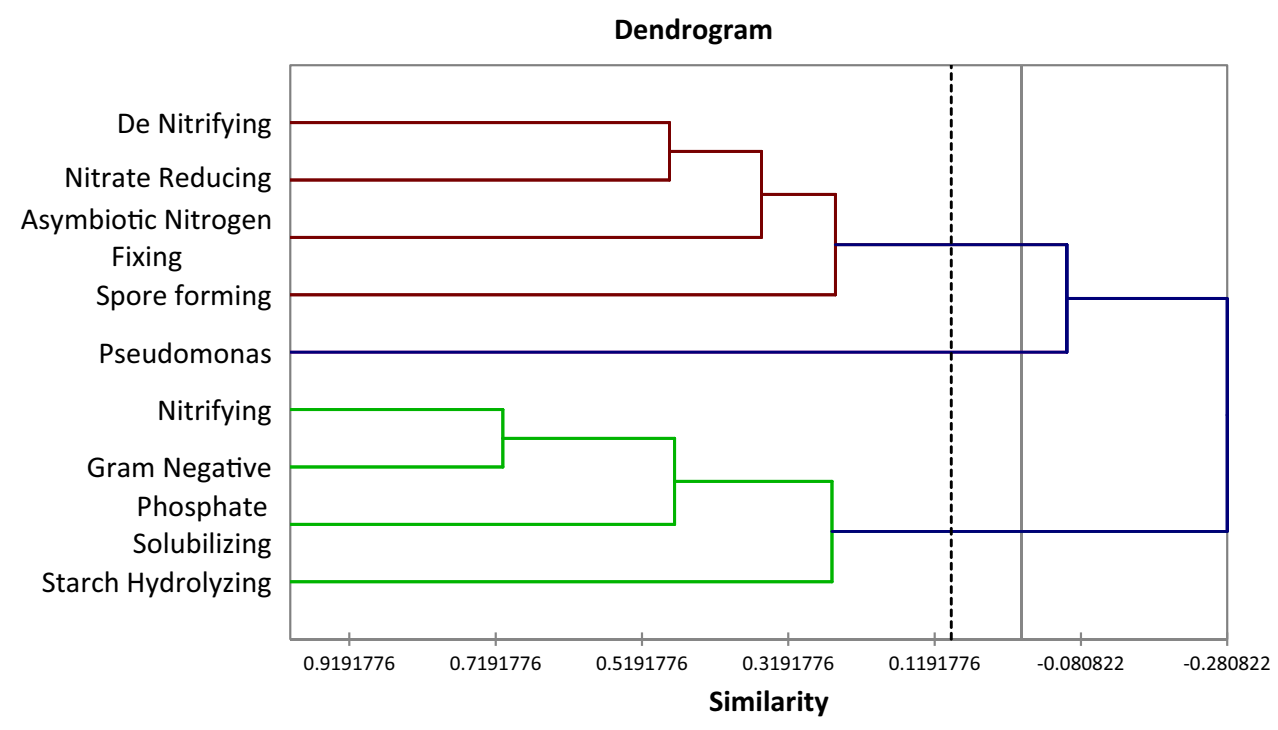

Table 3 Eigenvalues extracted from the Principal Component Analysis

\begin{tabular}{lrrr}
\hline & F1 & \multicolumn{1}{c}{ F2 } & \multicolumn{1}{c}{ F3 } \\
\hline Eigenvalue & 3.541 & 1.603 & 1.391 \\
Variability (\%) & 39.349 & 17.808 & 15.456 \\
Cumulative \% & 39.349 & 57.156 & 72.613 \\
\hline
\end{tabular}

component analysis (PCA) three components were extracted having the Eigen values of 3.541, 1.603 and 1.391, respectively, that explained more than $72 \%$ (component $1-39.35 \%$, component $2-17.8 \%$ and component $3-15.45 \%$ ) of the variance on the microbial abundance in the soil samples of the coastal areas of Digha (Table 3; Fig. 2). The bacterial groups were plotted on quadrant plot and among the four quadrants, starch-hydrolyzing bacteria were on the first quadrant, the second quadrant comprised of phosphate-solubilising, Gram-negative and nitrifying bacterial groups. Spore-forming, nitrate-reducing and denitrifying bacteria were in the third quadrant and the fourth quadrant contained Pseudomonas and asymbiotic nitrogen-fixing bacteria (Fig. 3). Shannon-Wiener and Simpson Index of the study areas ranged from 1.56 to 1.88 and 3.85-5.73, respectively. Jatimati showed comparatively higher diversity index among the villages of the study area (Table 4).

\section{Discussion}

Physicochemical properties of soil, such as textures, water holding capacity, $\mathrm{pH}$, organic matter content, etc. can influence microbial community structure by providing specific habitats for specific microorganisms (Chatterjee et al. 2014). The soil-inhabiting microorganisms play a vital role in regulating soil function by contributing to soil 


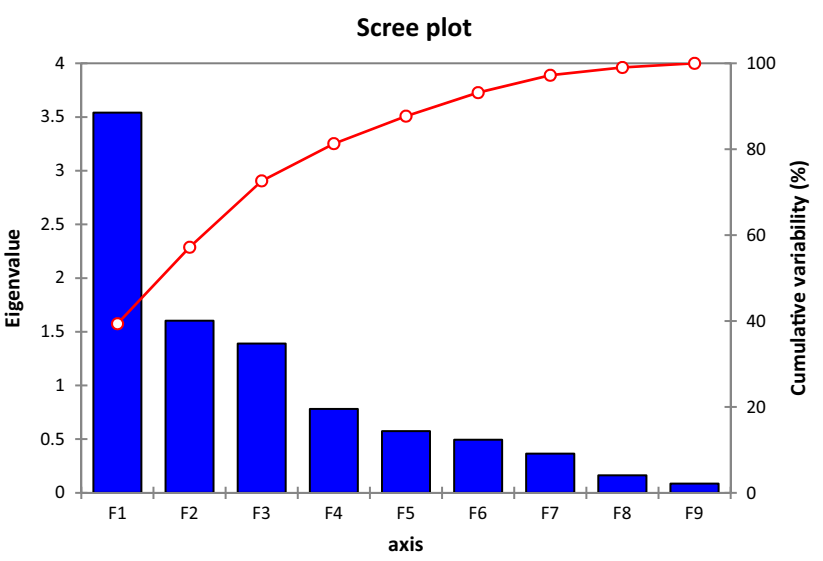

Fig. 2 Scree plot derived from PCA regarding the bacterial isolates of the collected soil samples of coastal areas of Digha, West Bengal, India

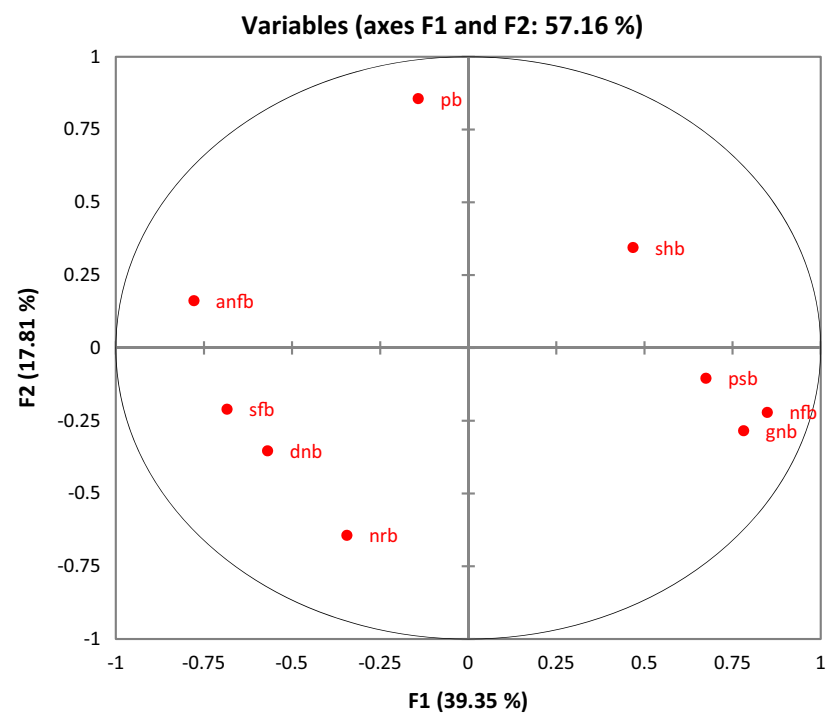

Fig. 3 Quadrant distribution of the soil bacterial isolates of the coastal areas of Digha, West Bengal, via PCA. anfb asymbiotic nitrogen-fixing bacteria, $p b$ Pseudomonas bacteria, shb starchhydrolyzing bacteria, $p s b$ phosphate-solubilising bacteria, $n f b$ nitrifying bacteria, gnb Gram-negative bacteria, nrb nitrate-reducing bacteria, $d n b$ denitrifying bacteria, $s f b$ spore-forming bacteria

structure formation (Wright and Upadhyaya 1998; Dodd et al. 2000), plant nutrition (George et al. 1995; Timonen et al. 1996), plant health (Srivastava et al.1996; Filion et al. 1999) and soil fertility (Yao et al. 2000; O’Donnell et al. 2001). So quantitative and qualitative assay of soil microbes is an essential part in characterization of soil (Arunachalam and Arunachalam 2000). Ranjard and Richaume (2001) have done such characterization in France. Das et al. (1997) and Das and Dangar (2008) have studied the microbial diversity in the soils of Himalayan region and saline soils of rice field of coastal Orissa. In the present study, viable plate count method was adopted to
Table 4 Soil bacterial diversity indices of different villages of coastal areas of Digha, West Bengal, India

\begin{tabular}{lll}
\hline Place & Shannon-Wiener Index & Simpson's index \\
\hline Padima & 1.8614581 & 5.4290517 \\
Jatimati & 1.8814364 & 5.726694 \\
Chanpabani & 1.5576826 & 3.9089861 \\
Palsandapur & 1.7972952 & 5.2850797 \\
Bhagibaharampur & 1.6336093 & 3.8501342 \\
Duttapur & 1.6592783 & 4.231307 \\
Gadadharpur & 1.6203932 & 4.0984608 \\
Gobindabasan & 1.7516001 & 4.6757094 \\
Somaibasan & 1.7141768 & 4.5963072 \\
\hline
\end{tabular}

assess the microbial diversity in the soil samples. In coastal areas of Digha, the aerobic heterotrophic bacterial population was quite lower than that in forest soil, agricultural and botanic soils of different parts of India. It was previously recorded that the heterotrophic bacterial population was found to be lower in sandy soils due to lower organic content than clay or humus soils (Kaur and singh 2000). The higher salinity might also be the reason of lower density of heterotrophic bacteria in coastal saline soils. Gram-positive bacterial Population was generally higher than Gram-negative bacterial Population, probably due to the ability of Gram-positive bacteria to form endospores and develop other stress response mechanisms (Hecker et al. 2007). Aerobic endospore-formers were found to be important in the soil nutrient cycle, such as the nitrogen cycle was influenced by denitrifiers, nitrogen fixers and organic nitrogen degraders; so as the sulphur cycle by sulphur oxidizers; and in transformation of other soil nutrients, such as manganese reduction. The abilities of the spore-forming bacteria to break down cellulose, hemicelluloses and pectins would suggest their roles in mineralization of plant material and humic material, while chitinase activity might help in degradation of fungal cell walls and insect exoskeletons (Mandic-Mulec and James 2011). In this study it was observed that spore-forming bacteria clustered with denitrifying, nitrate reducing with asymbiotic nitrogen-fixing bacteria (Fig. 1). May be the spore-forming isolates provided nutrients that help these other organisms to grow. According to van Gestel et al. (1996), the vicinity between microbes, organic matter and clay is required for the survival of microbes, in which the organic matter and clay particles provide substrates to live in and nutrients to grow and function. In a study in Orissa, Dangar et al. (2010) found that denitrifying bacterial population was high in flooded or water saturated soil. Probably moisture content was inversely and organic content was directly related to the density of microbial population (Pankhurst et al. 1996; Reichardt et al. 2001). In 
Palsandapur area, the phosphate content was much higher than in other places of the study sites (Table 2) that might favour the growth of phosphate-solubilising bacteria in this soil. The higher nitrogen content in Gadadharpur soil sample might be due to the high density of asymbiotic nitrogen-fixing bacteria in that soil. Asymbiotic nitrogenfixing bacteria could fix the nitrogen as nitrate which increased the nitrogen availability in soil. Shannon-Wiener Index and Simpson Index showed that Jatimati area was most diversified area in respect of soil microbial diversity among all the studied areas. The higher organic carbon, nitrogen and phosphate content of this area provided an apt environment for the bacterial communities. The ANOVA result indicated a variation in the relative density of the microbes present in the soils sampled during the study $(p<0.05)$. This variation was dependent on the microhabitat they were provided in different locations of the study area. The AHC analysis revealed the correlation between the bacterial groups in terms to their relative density which was further justified by PCA. The PCA helped to understand the correlation between the different bacterial groups based on their abundance in different soil samples of the coastal areas of Digha. Gomoryova et al. (1999) assessed the distribution of functional groups of microbes via BIOLOG analysis, and his further analysis concluded that two environmental variables, i.e. tree influence potential and organic carbon content of soil, significantly influenced the microbial composition of a particular soil.

\section{Conclusion}

This study can be considered as a promising start for identification and distribution of various bacterial families in different soil samples of the coastal areas of Digha, West Bengal, India. Though this is a preliminary work regarding the assessment of bacterial diversity, it can be helpful for further specific identification and characterization of the bacterial communities inhabiting the coastal area. The diversity of spore-forming bacteria in this area increases the chance of the availability of potential insect pathogens which may be helpful in the studies regarding biocontrol.

Acknowledgments Authors are grateful to University Grants Commission (MANF). The authors are thankful to Dr. A.M. Barik, Department of Zoology, The University of Burdwan, for his valuable suggestions.

\section{Compliance with ethical standards}

Conflict of interest Declared none.

Open Access This article is distributed under the terms of the Creative Commons Attribution 4.0 International License (http:// creativecommons.org/licenses/by/4.0/), which permits unrestricted use, distribution, and reproduction in any medium, provided you give appropriate credit to the original author(s) and the source, provide a link to the Creative Commons license, and indicate if changes were made.

\section{References}

Alexander M (1978) Introduction to soil microbiology, 2nd edn. Wiley Eastern Limited, New Delhi, p 465

Arunachalam A, Arunachalam K (2000) Influence of gap size and soil properties on microbial biomass in a subtropical humid forest of north-east India. Plant Soil 223:185-193

Atlas RM, Bertha R (1998) Mirobial ecology; fundamentals and applications, 4th edn. Pearson Education (Indian Branch), New Delhi, p 704

Breure AM (2004) Soil biodiversity: measurements, indicators, threats and soil functions. international conference, soil and compost biology, Leon-Spain Session 1, Paper 3, p 96

Chatterjee SN, Bhattacharya T, Dangar TK, Chandra G (2007) Ecology and diversity of Bacillus thuringiensis in soil environment. Afr J Biotechonol 6(13):1587-1591

Chatterjee SN, Syed AA, Mukhopadhyay B (2014) Diversity of soil bacteria in some village areas adjoining to Joypur forest of Bankura District of West Bengal, India. Int J Env Biol 4(1):67-70

Dangar TK, Babu YK, Das J (2010) Population dynamics of soil microbes and diversity of Bacillus thuringiensis in agricultural and botanic garden soils. Afr J Biotechnol 9:496-501

Das J, Dangar TK (2007) Diversity of Bacillus thuringiensis in the rice field soils of different ecologies in India. Ind J Microbiol 47:364-368

Das J, Dangar TK (2008) Microbial population dynamics, especially stress tolerant Bacillus thuringiensis, in partially anaerobic rice field soils during post-harvest period of the Himalayan, island, brackish water and coastal habitats of India. World J Microbiol Biotechnol. doi:10.1007/s11274-007-9620-3

Das AK, Boral L, Tripathi RS, Pandey HN (1997) Nitrogen mineralization and microbial biomass- $\mathrm{N}$ in subtropical humid forest of Meghalaya, India. Soil Biol Biochem 29:1609-1612

Dodd JC, Boddington CL, Rodriguez A, Gonzalez-Chavez C, Mansur I (2000) Mycelium of arbuscular mycorrhizal fungi (AMF) from different genera: form, function and detection. Plant Soil 226:131-151

Evangelou VP (1998) Environmental soil and water chemistry. Wiley, New York

Filion M, St-Arnaud M, Fortin JA (1999) Direct interaction between the arbuscular mycorrhizal fungus glomus intraradices and different rhizosphere microorganisms. New Phytol 141:525-533

George E, Marschner H, Jakobsen I (1995) Role of arbuscular mycorrhizal fungi in uptake of phosphorus and nitrogen from the soil. Crit Rev Biotechnol 15:257-270

Gomoryova E, Hrivnak R, Janisova M, Ujhazy K, Gomory D (1999) Changes of the functional diversity of soil microbial community during the colonization of abandoned grassland by a forest. Appl Soil Ecol 439(2-3):191-199

Hecker M, Pané-Farré J, Völker U (2007) SigB-dependent general stress response in Bacillus subtilis and related gram-positive bacteria. Annu Rev Microbiol 61:215-236

Holt JG (1986) Bergey's manual of systematic bacteriology, vol I. Williams Wilkins, Baltimore, pp 1-964

Issac RA, Johnson WC (1984) Methodology for the analysis of soil (revised). University of Georgia, Athens

Kaur S, Singh A (2000) Natural occurrence of Bacillus thuringiensis in leguminous phylloplanes in New Delhi region of India. World J Microbiol Biotechnol 16:679-682 
Kinnear PR, Gray CD (2000) SPSS for windows made simple, release 10. Psychology Press, Sussex

Lacey LA (1997) Manual of techniques in insect pathology. Academic Press, New York

Mandic-Mulec I, James IP (2011) Diversity of endospore-forming bacteria in soil: characterization and driving mechanisms. In: Logan NA, De Vos P (eds) Endospore-forming soil bacteria, soil biology, 27. Springer-Verlag, Berlin, Heidelberg

Manly BFJ (1994) Multivariate statistical methods: a primer, II edn. Chapman and Hall, London

O’Donnell AG, Seasman M, Macrae A, Waite I, Davies JT (2001) Plants and fertilizers as drivers of change in microbial community structure and function in soil. Plant Soil 232:135-145

Pandey RR, Sharma G, Tripathi SK (2007) Litterfall, litter decomposition and nutrient dynamics in a subtropical natural oak forest and managed plantation in northeastern India. Forest Ecol Manage 240:96-104

Pankhurst CE, Opjel-keller K, Doube BM, Gupta VVSR (1996) Biodiversity of soil microbial communities in agricultural systems. Biodiver Conserv 5:202-209

Pelczar MJ Jr, Bard RC, Burnett GW, Conn HJ, Demoss RD, Euans EE, Weiss FA, Jennison MW, Meckee AP, Riker AJ, Warren J, Weeks OB (1957) Manual of microbiological methods. McGraw Hill Book Company Inc, New York

Ranjard L, Richaume A (2001) Quantitative and qualitative microscale distribution of bacteria in soil. Res Microbiol 152:707-716. doi:10.1016/S0923-2508(01)01251-7

Reichardt W, Briones A, de Jesus R, Padre B (2001) Microbial population shifts in experimental rice systems. Appl Soil Ecol $17: 151-163$

Satyanarayana T, Raghukumar C, Shivaji S (2005) Extremophilic microbes: diversity and perspectives. Curr Sci 89(1):78-90
Seckbach J (2000) Journey to diverse microbial worlds, vol 2. Kluwer Academic Publishers, Dordreched

Srivastava D, Kapoor R, Srivastava SK, Mukerji KG (1996) Vesicular arbuscular mycorrhiza: an overview. In: Mukerji KG, Chamola BP, Singh J (eds) Concepts in mycorrhizal research. Kluwer Academic Publishers, Netherlands, pp 1-39

Sumner ME, Miller WP (1996) Cation exchange capacity and exchange coefficients. Book Ser. 5. SSSA and ASA, Soil science society of America, Madison

Timonen S, Finlay RD, Olsson S, Soderstrom B (1996) Dynamics of phosphorous translocation in intact ectomycorrhizal systems: non-destructive monitoring using a B-scanner. FEMS Microbiol Ecol 19:171-180

van Gestel M, Merckx R, Vlassek K (1996) Spatial distribution of microbial biomass in microaggregates of a silty-loam soil and the relation with the resistance of microorganisms to soil drying. Soil Biol Biochem 28:503-510

Visalatchi A, Raj Chandar P (2012) Land use and land cover mapping and shore line changes studies in Tuticorin coastal area using remote sensing. Int J Adv Earth Sci Eng 1(1):1-12

Wright SF, Upadhyaya A (1998) A survey of soils for aggregate stability and glomalin, a glycoprotein produced by hyphae of arbuscular mycorrhizal fungi. Plant Soil 198:97-107

Yao K, Hahn D, Honerlage W, Schonholzer F, Zeyer J (2000) In situ detection of spores and vegetative cells of Bacillus megaterium in soil by whole cell hybridization. Syst Appl Microbiol 18:265-273

Zar JH (1999) Biostatistical analysis, 4th edn. Pearson Education Private Limited (Indian Branch), New Delhi 